University of Michigan Law School

University of Michigan Law School Scholarship Repository

Law \& Economics Working Papers

$11-20-2017$

\title{
Once More, with Feeling: The 'Tax Cuts and Jobs' Act and the Original Intent of Subpart F
}

\author{
Reuven S. Avi-Yonah \\ University of Michigan Law School, aviyonah@umich.edu \\ Nir Fishbien \\ University of Michigan Law School, nirf@umich.edu
}

Follow this and additional works at: https://repository.law.umich.edu/law_econ_current

Part of the Law and Economics Commons, and the Tax Law Commons

\section{Working Paper Citation}

Avi-Yonah, Reuven S. and Fishbien, Nir, "Once More, with Feeling: The 'Tax Cuts and Jobs' Act and the Original Intent of Subpart F" (2017). Law \& Economics Working Papers. 143.

https://repository.law.umich.edu/law_econ_current/143

This Article is brought to you for free and open access by University of Michigan Law School Scholarship Repository. It has been accepted for inclusion in Law \& Economics Working Papers by an authorized administrator of University of Michigan Law School Scholarship Repository. For more information, please contact mlaw.repository@umich.edu. 


\title{
ONCE MORE, WITH FEELING: THE “TAX CUTS AND JOBS” ACT AND THE ORIGINAL INTENT OF SUBPART F
}

\author{
Reuven S. Avi-Yonah1 \\ Nir Fishbien ${ }^{2}$
}

For the first time since 1913, Congress is considering abandoning the principle that US residents should be subject to tax on all income "from whatever source derived." 3 Specifically, the proposed tax reform legislation, the so-called "Tax Cuts and Jobs Act", would completely exempt from US taxation dividends from "Controlled Foreign Corporations" (CFCs). ${ }^{4}$ This is therefore a good occasion for considering the reasons we tax such dividends in the first place.

When the modern income tax was adopted in 1913, it was clear that as a jurisdictional matter the US could not tax non-residents on foreign source income. ${ }^{5}$ While US residents are subject to tax on all income "from whatever source derived" under the provisions of IRC sections 1 and 11, in the case of non-residents, IRC sections 2(d) and 11(b) limit the tax to US source income. ${ }^{6}$ That, plus the definition of a US resident corporation as a corporation incorporated in the United States, meant that the income tax did not apply to a foreign corporation earning foreign source income even if it was $100 \%$ controlled by a single US shareholder. ${ }^{7}$

By the 1930s, it became clear that this situation was untenable, because Congressional hearings revealed that wealthy US individuals used "incorporated

\footnotetext{
${ }^{1}$ Irwin I. Cohn Professor of Law, the University of Michigan.

2 S.J.D. candidate, the University of Michigan.

${ }^{3}$ IRC section 61; US Constitution, Amendment XVI.

${ }^{4}$ Tax Cuts and Jobs Act of 2017, H.R. 1 (Nov. 2, 2017) (TRA17), section 4001.

5 This view has since been relaxed for foreign corporations controlled by US residents. See Avi-Yonah, International Tax as International Law, 57 Tax L. Rev. 483 (2004).

${ }^{6}$ IRC section 2(d): In the case of a nonresident alien individual, the taxes imposed by sections 1 and 55 shall apply only as provided by section 871 or 877 . IRC section 11(d): In the case of a foreign corporation, the taxes imposed by subsection (a) and section 55 shall apply only as provided by section 882 .

7 If we had adopted the UK definition of residence as where the corporation is managed and controlled from, this situation would frequently have resulted in the corporation being a US resident. This is still the best remedy against inversions, especially if combined with a corporate exit tax to deter moving the headquarters. There are no inversions in Europe because they adopted both measures. If we abolish deferral as argued below, we need to adopt both of these defensive measures.
} 
pocketbooks" in tax havens to accumulate income offshore and avoid US tax. In some cases, they then gave up their US citizenship and moved abroad to enjoy the accumulated income. Congress responded by enacting the Foreign Personal Holding Company (FPHC) provisions (IRC 551 et seq.), which taxed the profits of a FPHC if it had over $60 \%$ passive income and was controlled by five or fewer US individuals. ${ }^{8}$ However, Congress was careful not to violate the basic jurisdictional limitation by taxing the FPHC directly (unlike its domestic cousin the Personal Holding Company, which was subject to tax at the top individual rate but at the corporate level). Instead, Congress invented the deemed dividend concept, under which the controlling shareholder was deemed to receive a dividend from the FPHC and was taxed on the dividend. ${ }^{9}$ This provision was upheld against a constitutional challenge. ${ }^{10}$

In 1961, the Kennedy Administration proposed extending the deemed dividend rule to all the income of CFCs operating in developed countries. The reasons cited by the Administration included (a) capital export neutrality (CEN), a new concept invented by economists in the 1950s; (b) the need to preserve the US balance of payment position against too many dollars flowing out as foreign direct investment (FDI); and (c) the need to protect the US corporate tax base from income shifting. ${ }^{11}$

Of these three reasons, the first is problematic and the second is obsolete. CEN is problematic because in recent years many economists have raised doubts on its importance in comparison to Capital Import Neutrality (CIN) or Capital Ownership Neutrality (CON)..$^{12}$ The balance of payments issue is obsolete because since the US abandoned the gold standard in 1971 it does not care about how many dollars are in foreign hands because it can always print more. ${ }^{13}$

8 The FPHC regime was repealed in 2004 as redundant with PFICs (1986).

${ }^{9}$ See Avi-Yonah, The Deemed Dividend Problem, 4 J. Taxation Global Transactions 33 (2004), also in Proceedings of the National Tax Assoc. Annual Meeting (2004).

${ }^{10}$ Eder v. Commissioner of Internal Revenue, 138 F.2d 27 (2d Cir. 1943).

${ }^{11}$ See President Kennedy's Tax Message to Congress, April 20, 1961, http://www.presidency.ucsb.edu/ws/?pid=8074, reprinted in part below. ${ }^{12}$ See Hines, "Reconsidering the Taxation of Foreign Income." Tax L. Rev. 62, no. 2 (2009): 269-98; Hines, Desai and Foley, "Taxation and Multinational Activity: New Evidence, New Interpretations." Surv. Current Bus. 86, no. 2 (2006): 16-22.

${ }^{13}$ In any event, the mere use of tax laws to address the balance of payments problem was, to a certain extent, problematic, as more immediate and flexible tools could have been more responsive to the problem: "From a more general standpoint, various questions can be raised about the United States approach of considering the tax laws from a balance of payments and foreign economic policy standpoint... More immediate and flexible tools may be more responsive to policy needs. Thus, most of the European countries, during the period when they experienced balance of payments difficulties, resorted to direct controls such as capital and exchange controls. The United States reluctance to resort to direct controls makes it necessary to consider indirect tools, such as the tax Jaws, but the question can be asked 
This leaves the third reason: protecting the US corporate tax base from income shifting. The first author has previously argued that this was the main impetus behind the Kennedy Administration's push to abolish deferral. ${ }^{14}$ This view can now be supported by a remarkable report from the Stanley Surrey papers at Harvard Law School.

This report is dated March 10,1961, a little over a month before President Kennedy's tax message to Congress (April 20,1961). It was forwarded to the new Assistant Secretary for Tax Policy Stanley S. Surrey from IRS Commissioner Mortimer Caplin. The report explains some of the problems encountered by the IRS in the international arena, including "problems relating to the retention of foreign profits abroad, including (a) accumulation of earnings by operating companies and (b) accumulation of earnings by base companies in tax haven countries." It then goes on to explain why this was a problem:

The consensus of the task force is that under our basic philosophy of taxation, United States taxpayers with foreign income should be taxed as much as the United States taxpayer with similar domestic income for reasons of equity among taxpayers and the prevention of tax avoidance. This view is consistent with the idea that income taxes are imposed on a concept of ability to pay and where income is received from any source, the ability to pay is not different merely because the source of income may be from a foreign area. ... It is our view that the first objective should be an attempt to achieve equality between the taxation of domestic and foreign income. This is based on the thought that tax preferment, even for the most laudable purposes, always gives rise to attempts on the part of some to avail themselves of such preferment when their operations are without real purpose. This automatically gives rise to questions of avoidance and evasion. This in turn obviously makes the administrative job more difficult. 15

The task force then goes on to recommend limits on deferral, namely "add new section 951 et seq. to provide for a foreign personal holding company type tax on all earnings and profits of a base company controlled by a small number of US shareholders."

whether other countries which have used direct controls do not have adequate means to solve their problems so that it would not be necessary on economic grounds to consider the tax laws in this respect". See Stanford G. Ross, Report on the United States Jurisdiction to Tax Foreign Income, 49b STUD. ON INT'L FISCAL L. 184, 217 (1964).

${ }^{14}$ Avi-Yonah, All of a Piece Throughout: The Four Ages of U.S. International Taxation, 25 Virginia Tax Rev. 313 (2005).

${ }^{15}$ Stanley Surrey papers, Harvard Law School library, box 175-2b (emphasis added). The document is reproduced in part below. 
What is remarkable is that here there is no mention at all of either neutrality (of any kind) or the balance of payments. Instead, the proposed Subpart F (with the correct Code section) is based entirely on preventing income shifting.

We can now compare this to President Kennedy's message to Congress on April 20, 1961:

\section{TAX TREATMENT OF FOREIGN INCOME}

Changing economic conditions at home and abroad, the desire to achieve greater equity in taxation, and the strains which have developed in our balance of payments position in the last few years, compel us to examine critically certain features of our tax system which, in conjunction with the tax system of other countries, consistently favor United States private investment abroad compared with investment in our own economy.

1. Elimination of tax deferral privileges in developed countries and "tax haven" deferral privileges in all countries. Profits earned abroad by American firms operating through foreign subsidiaries are, under present tax laws, subject to United States tax only when they are returned to the parent company in the form of dividends. In some cases, this tax deferral has made possible indefinite postponement of the United States tax; and, in those countries where income taxes are lower than in the United States, the ability to defer the payment of U.S. tax by retaining income in the subsidiary companies provides a tax advantage for companies operating through overseas subsidiaries that is not available to companies operating solely in the United States. Many American investors properly made use of this deferral in the conduct of their foreign investment. Though changing conditions now make continuance of the privilege undesirable, such change of policy implies no criticism of the investors who so utilize this privilege.

The undesirability of continuing deferral is underscored where deferral has served as a shelter for tax escape through the unjustifiable use of tax havens such as Switzerland. Recently more and more enterprises organized abroad by American firms have arranged their corporate structures--aided by artificial arrangements between parent and subsidiary regarding intercompany pricing, the transfer of patent licensing rights, the shifting of management fees, and similar practices which maximize the accumulation of profits in the tax haven--so as to exploit the multiplicity of foreign tax systems and international agreements in order to reduce sharply or eliminate completely their tax liabilities both at home and abroad.

To the extent that these tax havens and other tax deferral privileges result in U.S. firms investing or locating abroad largely for tax reasons, the efficient allocation of international resources is upset, the initial drain on our already adverse balance of payments is never fully compensated, and 
profits are retained and reinvested abroad which would otherwise be invested in the United States. Certainly since the postwar reconstruction of Europe and Japan has been completed, there are no longer foreign policy reasons for providing tax incentives for foreign investment in the economically advanced countries.

If we are seeking to curb tax havens, if we recognize that the stimulus of tax deferral is no longer needed for investment in the developed countries, and if we are to emphasize investment in this country in order to stimulate our economy and our plant modernization, as well as ease our balance of payments deficit, we can no longer afford existing tax treatment of foreign income.

I therefore recommend that legislation be adopted which would, after a twostep transitional period, tax each year American corporations on their current share of the undistributed profits realized in that year by subsidiary corporations organized in economically advanced countries. This current taxation would also apply to individual shareholders of closely-held corporations in those countries. Since income taxes paid abroad are properly a credit against the United States income tax, this would subject the income from such business activities to essentially the same tax rates as business activities conducted in the United States. To permit firms to adjust their operations to this change, I also recommend that this result be achieved in equal steps over a two-year period, under which only one-half of the profits would be affected during 1962. Where the foreign taxes paid have been close to the U.S. rates, the impact of this change would be small.

This proposal will maintain United States investment in the developed countries at the level justified by market forces. American enterprise abroad will continue to compete with foreign firms. With their access to capital markets at home and abroad, their advanced technical know-how, their energy, resourcefulness and many other advantages, American firms will continue to occupy their rightful place in the markets of the world. While the rate of expansion of some American business operations abroad may be reduced through the withdrawal of tax deferral such reduction would be consistent with the efficient distribution of capital resources in the world, our balance of payments needs, and fairness to competing firms located in our own country.

At the same time, I recommend that tax deferral be continued for income from investment in the developing economies. The free world has a strong obligation to assist in the development of these economies, and private investment has an important contribution to make. Continued income tax deferral for these areas will be helpful in this respect. In addition, the proposed elimination of income tax deferral on United States earnings in 
industrialized countries should enhance the relative attraction of investment in the less developed countries.

On the other hand, I recommend elimination of the "tax haven" device anywhere in the world, even in the underdeveloped countries, through the elimination of tax deferral privileges for those forms of activities, such as trading, licensing, insurance and others, that typically seek out tax haven methods of operation. There is no valid reason to permit their remaining untaxed regardless of the country in which they are located. ${ }^{16}$

Here we have all three reasons- CEN ("efficiency"), balance of payments, and preventing income shifting/equity, with significant emphasis on the last one. This is consistent with the task force report as well as a later memorandum by Surrey (1962) we have published that agrees under pressure to limit the proposal just to tax haven operations that facilitate income shifting from the US. ${ }^{17}$

However, when Treasury Secretary Douglas Dillon came to present the proposal to the House Ways and Means Committee on May 3, 1961, his statement emphasized balance of payments and CEN, not anti-avoidance:

To avoid artificial encouragement to investment in other advanced countries as compared with investment in the United States, we propose that American corporations be fully taxed each year on their current share in the undistributed profits realized by subsidiary corporations organized in economically advanced countries...

While it is difficult to estimate quantitatively by how much tax deferral has contributed to the balance of payments deficit, it has surely been a significant factor...Today, our situation is such that we must look first to the more immediate balance of payments results...It may be estimated, although very roughly, that the elimination of the deferral privilege for subsidiaries in advanced countries and for tax haven operations in all countries would improve our balance of payments position by as much as $\$ 390$ million per annum...

While relief for the balance of payments is an important reason for discontinuing tax deferral, it is not the only one. There exists, in addition, an important issue of equity which has a significant bearing on domestic employment and production...With the present deferral privilege, an American firm contemplating a new investment and finding cost and market conditions comparable at home and abroad is impelled toward the investment opportunity overseas...

${ }^{16}$ Kennedy Tax Message, supra (emphasis added).

${ }^{17}$ Avi-Yonah, Territoriality and the Original Intent of Subpart F, 155 Tax Notes 1581 (June 12, 2017), 86 Tax Notes Int'l 1009 (June 12, 2017). 
It is sometimes contended that if US firms are to compete successfully abroad they must enjoy as favorable a tax treatment as their foreign competitors. I believe that this argument has been overly stressed...But even if this argument were fully valid, it could not be a decisive objection to our proposal. As long as the tax systems of various countries differ- and I venture to predict that this will be the case for years to come- we must make a form choice. Either we tax the foreign income of US companies at US tax rates and credit income taxes paid abroad, thereby eliminating the tax factor in the US investor's choice between domestic and foreign investment; or we permit foreign income to be taxed at the rates applicable abroad, thereby removing the impact, if any, which tax rate differences may have on the competitive position of the American investor abroad. Both types of neutrality cannot be achieved at once. I believe that reasons of tax equity as well as reasons of economic policy clearly dictate that in the case of investment in other industrialized countries we should give priority to tax neutrality in the choice between investment here and investment abroad. ${ }^{18}$

The National Foreign Trade Council, the lobbying arm of US-based multinationals (NFTC) in its 1999 critique of Subpart F emphasizes this statement much more than the President's tax message, because Dillon argued for abolishing deferral almost entirely in the name of balance of payments and economic neutrality considerations, with preventing income shifting almost entirely absent. ${ }^{19}$ This was of course convenient, because the NFTC could then present abolishing deferral as based entirely on discredited or obsolete arguments. ${ }^{20}$ But the document we reproduced

${ }_{18}$ President's Tax Message along with Principal Statement...Submitted by Secretary of the Treasury Douglas Dillon...Committee of Ways and Means, House of Representatives (May 3, 1961) (emphasis added).

${ }^{19}$ NFTC report, 1999: President Kennedy's 1961 proposals reversed Treasury's previous reluctance to endorse current taxation of foreign income and explicitly embraced capital export neutrality, due, in substantial part, to concerns with the U.S. balance of payments situation at the time...When he introduced the Treasury's specific suggestions for ending deferral, Secretary Dillon framed his suggestions largely in terms of capital export neutrality... The importance of capital export neutrality as a motivation for the proposal emerged most clearly in Secretary Dillon's preemptive strike against those who he predicted would argue that the end of deferral would undermine the competitive position of U.S. firms operating abroad...

${ }^{20}$ NFTC, 1999: By July 1961, the Treasury had retreated from its insistence on a general anti-deferral regime. Treasury then offered a more modest proposal that aimed to address only the use of tax havens. Treasury's new position marked its abandonment of a policy of capital export neutrality in U.S. international tax law and also was the beginning of the transformation of the Kennedy proposals into "antiabuse" provisions...The major shift recommended by the Kennedy Administration, to a general policy of capital export neutrality had been rejected...It is clear that 
above shows clearly that a policy of abolishing deferral could be based entirely on anti-avoidance considerations, without the need to invoke either the balance of payments or CEN.

The multinationals predictably objected in the name of competitiveness, and Congress agreed, even though at the time US multinationals dominated the world

neither the House nor the Senate embraced the Kennedy Administration's call to shift U.S. international tax law to a policy of capital export neutrality. Instead, the 1962 legislation, as ultimately enacted, was targeted at eliminating certain "abuses" permitted under prior law. The historical record, however, is far from clear about exactly what the "abuses" were that Congress intended to curb...The lack of clarity in the historical record of the 1962 Act about what constituted an abuse of tax deferral in international transactions has resulted in ongoing debates about the proper scope of subpart $\mathrm{F}$ that continue to this day. As subsequent chapters show, legislation since 1962 has changed the rules for when current taxation is required, but has not resolved the basic debate that raged in 1962. Moreover, interpretations of the 1962 Act subsequent to its enactment have sometimes described as abusive any transaction where a foreign government imposes lower tax than would be imposed by the United States on the same transaction or income.65 This cannot be right. In 1962, Congress clearly rejected making capital export neutrality the linchpin of U.S. international tax policy. Attempting to force a strained interpretation of the legislation it did enact into an endorsement of capital export neutrality by defining anything that departs from capital export neutrality as an abuse flagrantly disregards the historical record.

65 See Stanford G. Ross, Report on the United States Jurisdiction to Tax Foreign Income, 49b STUD. ON INT'L FISCAL L. 184, 212 (1964).

Interestingly enough, Ross, in the same 1964 report cited by the NFTC, stated that "[t]he United States 1962 legislation was primarily based on considerations of tax equity and providing neutrality in the tax treatment of foreign investment. At the same time, balance of payments and foreign economic policy objectives were in accord with these bases for change and so reinforced the case for change to a more equitable and neutral tax law in this area". See Ross, Report on the United States Jurisdiction to Tax Foreign Income, supra. It should also be noted that in the same report, Ross argued that the principle of "tax neutrality" had three major roots. The first of which was that "on grounds of equity, an American earning a dollar in Europe should pay the same tax as an American earning a dollar here at home". The second of which was economic and balance of payments considerations and the third was based on the ground of eliminating tax abuse "which undermined the integrity of the tax system" (emphases added). This is near contemporaneous evidence by a participant in the deliberations, and thus entitled to greater deference than the NFTC Report. 
(18 of the top 20 MNEs were American). ${ }^{21}$ Thus we got the Subpart F compromise under which passive income and base company income were taxed currently while active income continued to enjoy deferral. The Administration agreed because in 1962 it was hard to earn active income in low tax jurisdictions, so allowing deferral did not mean a strong incentive to shift. ${ }^{22}$

Subpart F operated more or less as intended until 1997, as shown by constant pressure by the multinationals through 1997 to relax its terms, e.g., by (a) abolishing IRC section $956 \mathrm{~A},{ }^{23}$ (b) providing that a CFC cannot be a PFIC, ${ }^{24}$ (c) introducing the active software royalties and active finance (banking and insurance) exceptions. ${ }^{25}$ In 1999, the NFTC issued a blistering attack on Subpart F and demanded abolishing the base company rule. ${ }^{26}$ However, "check the box" (adopted in 1997) was already doing its destructive work in undermining Subpart F27, and by 2004, when the Republicans had control of the White House and both houses of Congress, they passed legislation (the "American Jobs Creation Act") that was a Christmas tree laden with gifts for the multinationals without touching what remained of Subpart F. Then, as a final blow, IRC section 954(c)(6) was enacted in 2006 to make it difficult for a future Democratic Administration to revoke check the box. 28

${ }^{21}$ NFTC Report, 1999: "Competitiveness concerns were therefore central to the debate when subpart $\mathrm{F}$ was enacted in 1962, even at a time when U.S.-based companies dominated the international marketplace. In that year, 18 of the 20 largest companies in the world (ranked by sales) were headquartered in the United States, but this apparent dominance did not convince Congress that the competitive position of U.S. companies in international markets could be ignored. Thus, although the Administration originally proposed the acceleration of U.S. taxation of most foreign-affiliate income, that proposal was firmly rejected by Congress based largely on concerns about its competitive impact." On this report see Avi-Yonah, Tax Competition and Multinational Competitiveness: The New Balance of Subpart F, 18 Tax Notes Int'l 1575 (April 19, 1999).

${ }^{22}$ This is based on the statements of David Tillinghast reported in Avi-Yonah, U.S. Notice 98-11 and the Logic of Subpart F: A Comparative Perspective, Tax Notes Int'l (June 8, 1998).

${ }^{23}$ IRC 956A, enacted in 1993 and repealed in 1996.

${ }^{24}$ IRC 1297 (d)(1) (1997).

${ }^{25}$ IRC 543(a)(1)(C); IRC 954(h) (1997).

26 The NFTC Foreign Income Project: International Tax Policy for the 21st Century (1999).

${ }^{27}$ See Notice 98-11 (January 16, 1998), explaining how Treasury realized how check the box could be used to undermine Subpart F, and proposing to limit its application in the international arena. For an evaluation, see Avi-Yonah, Notice 98-11, supra. ${ }^{28}$ Which indeed they did not do when they had the majority in 2009-11. See AviYonah, President Obama's international tax proposals could go further, Columbia FDI Perspectives, No. 18, February 11, 2010. TRA17 would make IRC section 954(c)(6) permanent. 
So now we are in 2017, the GOP again controls the entire government, and tax reform is on the table once more. The main focus has by now moved to the $\$ 2.6$ trillion accumulated by the multinationals in low tax jurisdictions. The main goal of the NFTC and its allies is to ensure that this immense pile can be repatriated without too much tax (since they have mostly not taken a reserve against future tax on that income) and that future earnings can likewise be repatriated tax-free. Hence the proposal to overturn the "all income from whatever source derived" rule and permanently exempt dividends from CFCs. ${ }^{29}$

As Surrey would have predicted, the evisceration of Subpart $F$ by check the box and 954(c)(6) has led to an immense accumulation of profits in low tax jurisdictions. Moreover, just as he was concerned would happen, most of this pile stems from IP developed (with the costs of development deducted) in the United States. For example, Apple's $\$ 230$ billion in Ireland stem from the sales of devices whose value depends primarily on IP developed in Cupertino. ${ }^{30}$

What would happen if we adopt territoriality? The impetus to shift would be even stronger, because there will no longer be any reason to worry about being able to repatriate offshore profits. The resulting accumulations will dwarf even the \$2.6 trillion, just like the $\$ 2.6$ trillion dwarf the $\$ 300$ billion repatriated in the 2004-5 amnesty. ${ }^{31}$

But, the Republicans say, what about the anti-profit shifting provisions in TRA17? There are two major provisions. The first, section 4004 , imposes a $14 \%$ tax on past accumulations of cash or cash equivalents, and $7 \%$ on illiquid assets, payable over eight years.

This is higher than some observers have expected, given that most MNEs do not have a tax reserve for such payments on permanently invested income. However, there are three reasons to doubt the efficacy of this provision. First, given that by definition past accumulations have no impact on either efficiency or competitiveness, the rate should have been higher (35\% of $\$ 2.6$ trillion is $\$ 910$ billion, which would have offset much of the deficit increase from other provisions of TRA 17). Second, because the multinationals were aware that this provision is

${ }^{29}$ Avi-Yonah, Proposed Tax Plan Is Ripe for Abuse, The Century Foundation (October 27, 2017), https://tcf.org/content/commentary/proposed-tax-plan-ripeabuse/

${ }^{30}$ For Surrey's original views see the document reproduced in Avi-Yonah, Territoriality, supra.

${ }^{31}$ On the 2004 amnesty see Avi-Yonah, The Silver Lining: The International Tax Provisions of the American Jobs Creation Act-A Reconsideration, 59 IBFD Bulletin 27 (2005). Note that TRA17 keeps many of the current provisions that encourage profit shifting such as IRC 954(c)(6) that is made permanent (section 4204) and the active financing exception to Subpart F (section 4301). 
coming, they had ample opportunities to convert liquid to illiquid assets. Third, even worse, the provision depends on accumulated E\&P, and there are transactions that can be used to "vaporize" E\&P (e.g., IRC 304 transactions).

But this is just a transition issue. The main problem is the anti-shifting provision for future income, section 4301. Under that section, if a US parent corporation has "foreign high returns", defined as the aggregate return of its CFCs that exceeds 7\% plus the Federal short term rate on the CFCs aggregate adjusted bases in depreciable tangible property (the "trigger rate"), then it is subject to an immediate inclusion of $50 \%$ of its foreign high returns, i.e., an effective tax rate of $10 \%$, regardless of whether the earnings are repatriated.

Once again there are several reasons to doubt the effectiveness of this provision as an anti-shifting device. First, obviously $10 \%$ is better than $20 \%$ (the rate on domestic US income), and given the availability of the dividend exemption, there would be an incentive to shift profits in the knowledge that they can be repatriated at any time. Second, current foreign tax credits are available to offset the $10 \%$ tax, although only for $80 \%$ of foreign taxes paid, so there will be some double taxation. Third, the trigger rate will shield some multinationals more than others. Ironically, the more tangible assets you have offshore, the higher your trigger rate, so companies like Apple or GE that actually make things offshore will do much better than companies like Microsoft, Google or Amazon. This will be an inducement to move jobs (not just profits) offshore.

Moreover, section 4301 will have another perverse effect- it will induce inversions. If a company successfully inverts, it will not be subject to the foreign high return inclusion, and will be able enjoy zero tax on those like under current law, as opposed to up to $10 \%$.

There are several inbound provisions in TRA17 that are supposed to deter inversions. For example, under section 3301, net interest in excess of $30 \%$ of EBITDA will not be deductible. This rule is necessary to prevent negative tax rates in conjunction with expensing (section 3101) and the active foreign dividend exemption (section 4001). But (a) some interest will still be deductible, and (b) even though "no deductions for expenses properly allocable to an exempt dividend...would be taken into account," money is fungible, so that negative effective tax rates can be expected.

Moreover, even though the interest allowance is lower than current IRC 163(j) allows, it reduces the effective US tax rate from $20 \%$ to $14 \%$, and so an inversion can result in a US rate of 14 and a foreign rate of 0 , instead of a US rate of 20 and a foreign rate of 10 under 4301 without an inversion.

The other major inbound provisions are a limit on interest expense that does not allow the US subsidiary to be leveraged more than $10 \%$ over the leverage of its worldwide group (section 4302) and a new excise tax of $20 \%$ on deductible 
payments other than interest paid by a US corporation to a related foreign corporation (section 4303). The first does little to limit interest expense since the worldwide group can be leveraged as much as it wants. The excise tax can be avoided if the related foreign corporation chooses to treat the payments as ECI subject to $20 \%$ tax.

The excise tax certainly looks formidable on paper and is sure to enrage our treaty partners, who will see it as an indirect way to impose a withholding tax on royalties (contrary to article 12 of the tax treaties) as well as violating the arm's length standard of article 9 (because the excise tax applies to cost of goods sold between related parties, implying that it is inflated, regardless of what unrelated parties would have agreed upon). ${ }^{32}$ But the excise tax is also vulnerable to avoidance. Most importantly, if the foreign corporation chooses to treat the payments as ECI, it gets to deduct amounts "determined by reference to the profit margins reported on the group's consolidated financial statements for the relevant product line." This suggests deductions for royalties as well as cost of goods sold will continue with no excise tax and no reference to arm's length comparables (which frequently do not exist).

In addition, the excise tax only applies to deductible payments to related parties. An inverted multinational can sell as much as it wants directly to US customers or to unrelated US distributors and it will avoid the excise tax. Therefore, inversions will continue, and TRA17 does not have any of the anti-inversion provisions that have been suggested (e.g., redefining corporate residence by location of headquarters and imposing a corporate exit tax analogous to IRC 877A).

TRA17's international provisions will therefore do little to prevent the kind of profit shifting that Subpart F was enacted to prevent. We should go back to the original intent of Subpart $\mathrm{F}$ and subject foreign income to the same rate as domestic income. ${ }^{33}$ We do not care too much what that rate is, although we believe the effective rate of our competitors is above $20 \%$ so $20 \%$ would preserve competitiveness. ${ }^{34}$ But the absolute key is to have the same rate on all income, domestic and foreign, because as the IRS task force wrote in 1961, "tax preferment, even for the most laudable purposes, always gives rise to attempts on the part of

32 Query how the excise tax can be defended in the WTO. On its face, it would seem to violate either GATT II:1(b) [as an unscheduled charge on importation that is not an "ordinary customs duty"], or GATT III:2 [as a discriminatory internal tax, if it is regarded as a tax on the internal sale to the subsidiary that just happens to be collected at the border]. The interaction between TRA17 and tax treaties deserves a separate paper.

33 This would, of course, take care of the lock out issue that animates the dividend exemption proposal.

34 Avi-Yonah and Lahav, The Effective Tax Rates of the Largest US and EU Multinationals, 65 Tax L Rev 375 (2012). We should also include anti-inversion provisions as suggested above. 
some to avail themselves of such preferment when their operations are without real purpose. This automatically gives rise to questions of avoidance and evasion."

A task force was established in the Service February 13, 1961 to study the tax effects of foreign operations by U. S. taxpayers. The group was assigned the following scope of inquiry:

1. What can the Service do in the foreign tax enforcement field under present law and regulations?

2. What legislative proposals can the Service recommend to Treasury for active consideration by Congress?

In considering these two questions the task force was to (1) identify and define the various specific problems and their situs, segregating them between (a) problems which can be solved under existing law and regulations, and (b) those requiring legislative actions; (2) immediately develop legislative recommendations needed under item 1 (b) with the objective of submitting some to Treasury for coordination with present legislative project of the International Tax Staff, which is scheduled for completion by April 1, 1961; (3) develop recommendations for suitable training of technical personnel in this specialized field of taxation; (4) develop effective guidelines, and (5) devote its attention to the general objective of conceiving plans and means for the improvement of our techniques and programs in this functional area.
} 
Mr. Stanley S. Surrey - 2 -

There is attached a report of the task force dated March 10, 1961 containing proposals for legislative action. Due to the urgency of getting this to you in order that your staff may consider the task force proposals in connection with the Department's recommendations to Congress in April, neither my top staff nor I have had an opportunity to review them. I hope you will understand, therefore, that the views expressed in the attachments do not necessarily represent the firm position of the Service. This material is forwarded merely for your consideration in connection with the development of the Department's legislative recommendations to Congress.

The task force will now undertake to study the tax enforcement problems under present law and regulations which we view as extremely important and which should be undertaken with dispatch. However, if the Service can be of further assistance in the development of the way we can be of service.

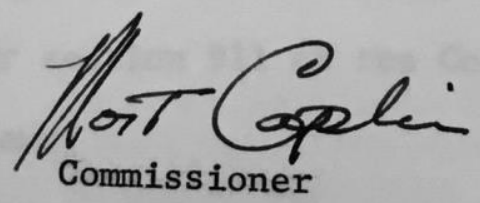


Avi-Yonah and Fishbien:

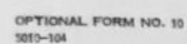

UNITED STATES GOVERNMENT

\section{Memorandum}

то : Director of International Operations DATE: MAR 101961

FROM : Task Force to Study Tax Effects of

Foreign Operations by U. S. Taxpayers

SUBJECT: Legislative Proposals

At the outset the task force identified seven general problem areas as follows:

1. Problems relating to the retention of foreign profits abroad including

(a) accumulation of earnings by operating companies and

(b) accumulation of earnings by base companies in tax haven countries;

2. Problems relating to the diversion of domestic profits abroad such as in the case of foreign reinsurance;

3. Sources of income rules especially as regards problems arising under the "passage of title" doctrine;

4. Exclusion of income under section 911 of the Code;

5. Foreign tax credit problems;

6. Administrative and summons procedures in obtaining information in cases such as Swiss numbered accounts, and

7. The withholding features of tax treaties.

These foregoing seven problem areas were assigned to various teams of the group who were allotted a two week period for consideration of the problems and preparation of proposals. Upon receipt of the proposals, reassignments of the same subjects were made to different team members for review and 
analysis. Other than the specific recommendations contained in this transmittal memorandum, the views expressed in the attachments reflect only the thinking of the individuals assigned to the specific problem.

The consensus of the task force is that under our basic philosophy of taxation, United States taxpayers with foreign income should be taxed as much as the United States taxpayer with similar domestic income for reasons of equity among taxpayers and the prevention of tax avoidance. This view is consistent with the idea that income taxes are imposed on a concept of ability to pay and where income is received from any source, the ability to pay is not different merely because the source of income may be from a foreign area. We are not unmindful of the fact that there are economic and political reasons which give rise to tax preferment under the Code. While we have made no attempt to weigh the relative merits of these economic and political arguments for or against such preferment, most of the proposals in the attachments are presented as alternatives from which those concerned with the economic and political considerations can make a selection as to what legislation should be recommended.

It is our view that the first objective should be an attempt to achieve equality between the taxation of domestic and foreign income. This is based on the thought that tax preferment, even for the most laudable purposes, always gives rise to attempts on the part of some to avail themselves of such preferment when their operations are without real purpose. This automatically gives rise to questions of avoidance and evasion. This in turn obviously makes the administrative job more difficult.

More and more students of taxation are considering the question of deferral of tax payment or a tax benefit from foreign operations. In almost every study the lack of information concerning the nature and extent of foreign 